\title{
Only the Brave: Product Innovation, Service Business Model Innovation, and Their Impact on Performance
}

ARTICLE in JOURNAL OF PRODUCT INNOVATION MANAGEMENT · DECEMBER 2014

Impact Factor: $1.7 \cdot$ DOI: 10.1111/jpim.12254

CITATIONS

3

3 AUTHORS:

Ivanka Visnjic

Universitat Ramon Llull

12 PUBLICATIONS 93 CITATIONS

SEE PROFILE

Andy Neely

University of Cambridge

147 PUBLICATIONS $\quad \mathbf{7 , 7 4 0}$ CITATIONS

SEE PROFILE
READS

160
Frank Wiengarten

Universitat Ramon Llull

35 PUBLICATIONS 312 CITATIONS

SEE PROFILE 
When citing this work, cite the original article below:

Visnjic, I., Wiengarten, F. and Neely, A. (2014), Only the Brave: Product Innovation, Service Business Model Innovation, and Their Impact on Performance. J Prod Innov Manag. doi:10.1111/jpim.12254

http://onlinelibrary.wiley.com/doi/10.1111/jpim.12254/abstract

Only the brave: product innovation, service business model innovation and their impact on performance

\section{Author Details}

Author 1 Name: Ivanka Visnjic (corresponding author) Department: Operations and Innovation Management Department University/Institution: ESADE Business School, Ramon Llull University Address: Av. Pedralbes, 60-62, 08034 Barcelona, Spain

Telephone number: +34664832427

E-mail: ivanka.visnjic@esade.edu

Author 2 Name: Frank Wiengarten Department: Operations and Innovation Management Department University/Institution: ESADE Business School, Ramon Llull University Address: Av. de la Torre Blanca, 59 E-08172 Sant Cugat, Spain

Telephone number: +34932 806162

E-mail: frank.wiengarten@esade.edu

Author 3 Name: Andy Neely

Department: Engineering University/Institution: Cambridge University

Address: 17 Charles Babbage Road, Cambridge CB3 OFS

Telephone number: +44 1223765608

E-mail: adn1000@cam.ac.uk 


\section{Author biographies}

\section{Ivanka Visnjic}

Ivanka Visnjic is an Assistant Professor at ESADE Business School and a Research Sponsor at Cambridge Service Alliance, University of Cambridge. Her research lies at the intersection of strategy, innovation and operations management and her focus is the emerging field of business model innovation. She studies how companies create value by shifting from product to service business models and proposes organizational solutions to the trade-offs associated with this shift. Furthermore, her research demonstrates how the interplay between business model innovation and product innovation or different market strategies affects value creation.

\section{Frank Wiengarten}

Frank Wiengarten is an Assistant Professor at ESADE Business School in the Department of Operations Management and Innovation. His research concerns supply chain management, strategy and sustainability. Besides environmental sustainability topics, his recent research efforts focus on the social sustainability side of supply chain management, i.e., occupational health and safety. He also studies the role of strategy on the management of operations and supply chains. Considering the alignment between contextual factors, corporate and operations strategy and performance outcomes. Previously he held appointments with the University College Dublin, Michael Smurfit Graduate Business School.

\section{Andy Neely}

Andy Neely is Founding Director of the Cambridge Service Alliance and the Royal Academy of Engineering Professor of Complex Services. He is widely recognized for his work on the servitization of manufacturing, as well as his work on performance measurement and management. Previously he has held appointments at Cranfield University, London Business School, Cambridge University, where he was a Fellow of Churchill College, Nottingham University, where he completed his $\mathrm{PhD}$ and British Aerospace. He was Deputy Director of AIM Research - the UK's management research initiative - from 2003 until 2012 and was elected a Fellow of the Sunningdale Institute in 2005, a Fellow of the British Academy of Management in 2007, an Academician of the Academy of Social Sciences in 2008, a Fellow of the European Operations Management Association in 2009 and President of the European Operations Management Association in 2013. 


\title{
Title:
}

Only the brave: product innovation, service business model innovation and their impact on performance

\begin{abstract}
:
Recent empirical findings concerning the performance effects of service business model innovation (servitization) and its interplay with product innovation are mixed. Using the lenses of the demand-based view on value creation and complementarity, the performance impact of two key service business models is examined: the product-oriented model and the customeroriented model, implemented jointly with product innovation. Results indicate that the interplay between service business model innovation and product innovation results in long-term performance benefits coupled with a degree of short-term performance sacrifice. Service business model innovation in isolation from product innovation results in short-term profit gains but long-term knowledge loss and, thus, market performance decline. Our study suggests that firms need to look beyond the evidence on short-term effects in order to achieve superior performance in the long run.
\end{abstract}

\section{Keywords:}

Servitization, product-service system, open-service innovation, resource-based view, customer utility, firm performance. 


\section{Introduction}

While the importance of product and business model innovations ${ }^{1}$ is now clearly established, our understanding of how firms create value by combining the two is incomplete (Zott et al. 2011). The literature has explored the value drivers that underpin product innovation, but the value drivers supporting business model innovation are far less developed (Amit and Zott 2001, 2012). Equally, the interplay between the two innovations is underexplored; the product innovation literature recognizes the need for a complementary business model and assets that underpin it, but it considers a business model as merely a complement to product innovation rather than a force for innovation and a factor of value creation in its own right (Chesbrough and Rosenbloom 2002; Gambardella and McGahan 2010; Leten et al. 2007). This article advances our understanding of the value-creating impact of business model innovation and the interplay (or mutual interdependency) between product and business model innovations.

Specifically, we focus on the highly prevalent service business model innovations of manufacturing firms and their interplay with product innovations (Neely 2008). Service business model innovation is the product of a servitization strategy, where a manufacturing firm with a product business model expands its offering into services related to its products and, as a result, shifts from the 'product-only' business model to the 'service-oriented' model (Cusumano et al. 2014). Servitization has received growing attention within the innovation community over recent years (Blindenbach-Driessen and van den Ende 2014; Ostrom et al. 2010). While often heralded as a move that creates value for the customer, its impact on the performance of the focal firm remains in question, partially due to the uncertain performance implications of the business model changes that underpin it (Fang et al. 2008; Martinez et al. 2010; Suarez et al. 2013). Indeed, differences in the reported performance effects could be due to differences in the sources of value creation among the service business models adopted (Eggert et al. 2011, 2014; Fang et al. 2008).

Furthermore, scholars have begun to examine the interplay between service business model innovation and product innovation (Chesbrough 2011a; Eggert et al. 2011). Interest in this interplay is not new, however; in the seminal article on profiting from innovation, Teece (1986) argues that complementary 'after-sales service' is often necessary to create and capture value from product innovation. For example, EMI's failure to reap significant returns from the CAT 
scanner it pioneered (Teece 1986), as well as Michelin's difficulty in driving market adoption for flat tire technology (Eggert et al. 2011), can both be attributed to the challenges for manufacturers in delivering services. On the other hand, some studies suggest that the relationship between servitization and product innovation may not be entirely complementary and that product innovation may have a negative impact on service business model innovation (Eggert et al. 2014; Gebauer 2011).

Given the contradictory nature of these findings, further research on the performance impact of servitization and, particularly, the product innovation-servitization relationship is needed (Chesbrough 2012). Thus, our research focuses on the question: "Does the concurrent adoption of service business models (servitization) and investment in product innovation result in significant performance benefits?". We apply the demand-based view on value creation (Priem 2007; Priem et al. 2012; Ye et al. 2012) and the complementarity perspective (Cassiman and Veugelers 2006; Ennen and Richter 2010; Milgrom and Roberts 1995) to derive hypotheses. To test these hypotheses, we compile an elaborate longitudinal data set with service variables derived from manually performed content analysis of publicly available information and financial data obtained from the secondary sources of 133 companies over a nine-year period. Our results suggest that service business models have a positive impact on value capture from product innovations in the long run but with some performance sacrifices in the short term. In contrast, the deployment of service business models without product innovation results in shortterm performance gains but long-term performance decline.

\section{Theoretical background}

\section{Product innovation, complementary assets and business models: identifying the service gap}

Literature has shown over a sustained period that product innovation has been considered one of the main drivers of value creation. Underpinned by technological change, this value creation stems from 'creative destruction' and the willingness to embrace risk and uncertainty; in effect, it destroys existing value in order to create new, superior value (Schumpeter 1942). Since Schumpeter's contribution, scholars have invested time and effort in coming to understand how companies acquire and develop technological capabilities as well as how they hone innovation processes to develop new products that generate the greatest value. Although our knowledge of 
product innovation has matured somewhat, many gaps remain. First, innovation is not limited to products and - in line with Schumpeter's initial definition - insufficient attention has been paid thus far to how other types of innovation create value, particularly business model innovation (Amit and Zott 2001; Snihur and Zott 2014). Second, the interdependencies between different types of innovation, while noted, have not been extensively explored (Snihur and Zott 2014; Zott and Amit 2008). Indeed, authors have already noted that product innovation in itself is likely to be insufficient and should, therefore, be accompanied by the appropriate business model (Chesbrough and Rosenbloom 2002; Teece 1986, 2010). These contributions, however, perceive the business model as a somewhat static factor that accompanies product innovation rather than a force for innovation and a source of value creation in its own right.

Business model innovation represents a change in the design of the activity system that spans the focal firm and its clients, partners, suppliers and other stakeholders involved in the process of creating value (Zott and Amit 2007). Drivers of value creation that underpin business model innovation have been more diverse, context-specific and less defined than those underpinning product innovation (Zott et al. 2011). Some effort has been made to define and group how business model innovation creates value. For instance, Amit and Zott (2001) group the value drivers of business model innovations for digital start-ups. They find that business model innovation helps e-businesses create value through an increase in novelty, efficiency, complementarity and lock-in. Understanding how incumbents, particularly in 'non-digital' sectors, create value through business model innovation is beginning to attract research interest (Zott et al. 2011). At the same time, the first contributions with respect to how manufacturing firms create value - specifically, the use value for customers - by shifting to service business models are beginning to appear (Raja et al. 2013).

Furthermore, the interplay between product innovation and business model innovation deserves greater attention. Researchers began to look at the supporting role that business models play in unlocking the value creation potential of technology change in the market place (Desyllas and Sako 2013; Gambardella and McGahan 2010), and they have increasingly argued that firms must consider how business model innovation and product innovation relate to one another (Chesbrough 2010; Desyllas and Sako 2013; Gambardella and McGahan 2010; Teece 2010). Some contributions investigating the impact of the business model on product innovation are already in place. For example, Chesbrough and Rosenbloom (2002) provide an interesting 
illustration of the impact that the business model has had on technological success by comparing six technologies commercialized by Xerox internally (using the 'pay-per-use' business model) with six that were commercialized by Xerox spin-offs.

Furthermore, while the business model provides a fairly holistic perspective of the entire activity system that needs to accompany product innovation, the notion that product innovation alone is insufficient is not new (Teece 1986; Winter 2006). In sectors characterized by weak appropriability regimes, where stronger innovation protections such as patents ${ }^{2}$ are ineffective, firms rely on the complementary assets to create value (Cohen et al. 2000; Helfat 1994; Teece 1986; Tripsas 1997). Teece (1982), for example, provides anecdotal evidence on how manufacturing, marketing and after-sales service activities help firms ensure value capture from products $^{3}$.

Even though giving consideration to the business model and the complementary assets that underpin it is very helpful, it does not consider business model innovation as an active driver of the value creation process, nor does it reflect on how the two innovations may influence each other (Zott and Amit 2008; Amit and Zott 2012). This gap is most acute in the case of service business model innovation, given that this business model innovation can be expected to be complementary to product innovation as well as substitutive (Chesbrough 2011a; Eggert et al. 2014; Visnjic Kastalli et al. 2013). The two sections that follow elaborate on these gaps (the value drivers of business model innovation and the interplay with product innovation) with respect to service business model innovation in particular.

\section{Servitization, service business models, value creation and performance: applying the demand perspective on value creation}

Servitization - the strategy employed by product providers to add accompanying services to their product range - has been a growing trend for manufacturing firms (Carlborg et al. 2014; Guajardo et al. 2011; Neely 2008; Ostrom et al. 2010; Vandermerwe and Rada 1988). Servitization has often been seen on a continuum from pure products to pure services, where the relative importance of services over products in the value proposition steadily increases (Chase 1981; Oliva and Kallenberg 2003; Raja et al. 2013). The nature of the services does not remain 
homogeneous along the innovation trajectory; firms begin with product-related services performed directly on products, such as repair, maintenance, and monitoring, and then gradually add customer-related services that support customer processes related to the use of the product, such as financing, leasing, insurance, training, and consulting (Eggert et al. 2011, 2014; Mathieu 2001; Raddats and Easingwood 2010). Thus, the servitization trajectory starts with the 'productonly' business model or the business model based solely on products and the provision of obligatory warranties or spare parts; it continues with the inclusion of product-related services (e.g. maintenance, repairs, and overhauls) in the 'product-oriented' business model, and it finally moves to the 'customer-oriented' business model as the firm gradually adds 'useoriented' and 'results-oriented' services (Gebauer 2008; Gebauer et al. 2012; Raja et al. 2013).

Even though this conceptualization of the servitization trajectory has been widely accepted, some have questioned a) whether this is the only possible trajectory and b) how far companies should go along it. Turunen (2011) found examples of firms that 'jump' from the product-only to the customer-oriented business model without passing through the 'product-related' business model stage. Moreover, certain instances have been noted where the customer-oriented business model was shaped by first taking on customer-related services and only then product-related services (Turunen 2011). Others questioned whether firms, out of necessity, need to 'go all the way' and may simply prefer to retain the product-oriented business model (Baines and Lightfoot 2013). Indeed, from the traditional resource-relatedness perspective, product-oriented services (e.g. product maintenance) are related to the design of the products and require similar knowledge and capabilities, whereas customer-oriented services (e.g. asset financing) are unrelated from the resource perspective (Fang et al. 2008).

Clearly, the adoption of a particular service business model will directly influence value creation and capture and will subsequently have performance implications. However, theorizing on value creation using the traditional perspectives, such as the resource-based view, has been problematic, and the empirical evidence on the performance effects of servitization has been largely phenomenon-driven and convoluted (Gebauer et al. 2012). Initially, servitization was praised as a route to growth, profitability and economic stability (Canton 1984; Cusumano 2004; Lele 1986; Quinn and Gagnon 1986; Spohrer and Maglio 2008; Van Looy et al. 2003). A number of more recent studies, however, reported mixed evidence concerning its impact on performance (see Gebauer et al. 2012 for an overview). Overall, research has identified a non- 
linear relationship between servitization and performance, in which a positive impact on performance only seems to (re)appear when a critical mass of services is achieved (Fang et al. 2008; Suarez et al. 2013; Visnjic Kastalli and Van Looy 2013). Furthermore, performance may be highly contingent on the nature and size of the service portfolio, customer proximity/centricity and resulting loyalty, organizational arrangements, and the type of industry (Eggert et al. 2014; Fang et al. 2008; Gebauer 2011; Neely 2008; Suarez et al. 2013; Visnjic Kastalli and Van Looy 2013).

Even though the traditional resource-based view (Barney 1991) has struggled to show how (and under which conditions) servitization creates value, the so-called demand-based view (Priem 2007; Ye et al. 2012) may offer additional insights (Visnjic Kastalli and Van Looy 2013). Proponents of this view show that companies can create value by saving time, effort and/or investments in learning for their customers and, thereby, generate 'economies of scope in use' (Ye et al. 2012) For example, Cottrell and Nault (2004) illustrated that a user of both word document editing software (e.g., Microsoft's Word) and the numerical software (e.g., Microsoft Excel) saves time and effort by transferring knowledge of the control panel from one software to another. Such learning economies stimulate intra-industry diversification, even when resourceside economies of scope are absent (Cottrell and Nault 2004). Second, Ye, Priem, and Alshwer (2012) considered another source of demand-side economies, which draws on the concept of the one-stop shop. Such economies occur where a collocated assortment of products or services reduce the time consumers need to search for products and purchase them.

From the demand-based perspective, both product-oriented and customer-oriented business models have a certain potential to create economies of scope in use compared to the product-only business model. In the case of the product-oriented business model, sourcing products and product-related services from the same provider can be seen as a 'one-stop shop' solution where customers save time, transaction costs and search costs by dealing with only one product-service provider (Ye et al. 2012). Customers may also reduce information asymmetries on product effectiveness, since procurement from the same provider means that (s)he can hold one organization accountable for the effectiveness of the product in use (Nayyar 1993; Visnjic Kastalli and Van Looy 2013). Hence, the following hypothesis is proposed: 
H1: The deployment of a product-oriented business model will result in a significantly higher profit margin, compared to the profit margin of a product-only business model.

Similarly, adding customer-related services to product-related services and products - hence, evolving from a product-related to a customer-related business model - would generate further economies of scope in use through saving customer time and effort, reducing informational asymmetries, and generating even higher value in the customer-oriented business model than in the product-oriented business model (Priem 2007; Ye et al. 2012). For example, a train equipment manufacturer offering maintenance agreements would help customers reduce negotiation and purchasing time by offering the product and the service as elements in a bundled solution. Given that performance contracts in the rail sector may take up to two years to negotiate and sign, this can be a significant reduction in costs on the customer side. Anticipated savings on the customer side will result in a greater willingness to pay and, subsequently, in higher profit margins for the manufacturer. Hence, the following hypothesis is proposed:

H2: The deployment of a customer-oriented business model will result in higher profit margins compared to the profit margins of a product-oriented business model.

\section{The impact of service business model innovation on product innovation and vice versa: applying the complementarity perspective}

Interest in the relationship between product innovation and servitization (service business model innovations) has been increasing steadily over recent years (Chesbrough 2011c; Gebauer 2011; Gebauer et al. 2008; Gremyr et al. 2010; Lightfoot and Gebauer 2011). To start with, a number of articles that focused on the effect of the provision of complementary services (service business model innovation) on product innovation argued for a positive relationship: provision of services can represent a useful opportunity for product manufacturers to learn about customers' product use, which can then be recycled into the product innovation exercise (Chesbrough 2011a; Visnjic Kastalli and Van Looy 2013). The case of LEGO, a toy manufacturer experiencing a revival in performance thanks to the website service that allows toy users to 
design their own toys, is instructive in this regard (Chesbrough 2011b). Moreover, Teece (1986) goes even further to suggest that, in some instances, product innovation cannot be profitable without a service business model. The case of EMI Corporation that failed to properly introduce CAT Scanners to the marketplace due to an inadequate capability to provide professional aftersales, training and consulting services to hospital buyers illustrates this assertion. At the same time, there are no empirical studies testing the performance effects of this relationship, and it is unclear whether this complementarity justifies substantial investment in service capabilities and the associated loss of focus.

Eggert et al. (2011), which empirically considers the effect of product innovation on service business model innovation, is less optimistic and suggests that the relationship may be characterized by tension and competition for firm resources. In addition, one may also surmise that product innovation has a negative impact on the ability of a firm to create value through services. Indeed, many product innovations are intended to reduce the need for servicing and to increase product autonomy and facilitate the automation of client processes. Admittedly, the evidence is incomplete: as with studies that look at how service business models influence product innovation, the evidence of the feedback relationship leaves the theorized positive impact of service business models on product innovations underexplored (Eggert et al. 2014).

Indeed, a conceptualization and testing that takes into consideration the impact of servitization on product innovation as well as product innovation on servitization is warranted. Even though some of the extant literature that follows Teece's argument (1986) describes their treatment of the product innovation and the service business model as complementary, this complementarity is actually conceptualized as solely unilateral (from service business model to product innovation). The complementarity perspective, however, views two activities as complementary when they are supermodular (Milgrom and Roberts 1995): when the marginal benefit to each activity is associated with an increase in the level of the other activity (Siggelkow and Levinthal 2003). Furthermore, complementarity literature may be helpful in identifying the factors that underpin the complementarity between these two innovations as well as measuring this construct (Ennen and Richter 2010).

Amongst other types of factor (strategy, structure, environment), resources and capabilities have been seen as the most prominent source of complementarity (Ennen and Richter 2010). Authors have, in particular, identified complementarities among capabilities (e.g. experience, 
knowledge, relationships, and intelligence), resources (e.g. technical or IT-related knowledge, internal R\&D, marketing knowledge) and technological assets (e.g. information or manufacturing technology) (see Ennen and Richter 2010 for the overview and references). In the context of quantitative testing, authors have operationalized the presence of complementarity as the interaction effect between the two factors. For example, Cassiman and Veugelers (2006) used the interaction effect to demonstrate that internal $R \& D$ and external knowledge acquisition are complementary innovation activities.

Traces of application of the complementarity perspective can be found in the service business model innovation literature as well. Visnjic Kastalli and Van Looy (2013) suggest that resources and activities that strengthen the product-oriented business model and resources that underpin product innovation (e.g. new product development) may be complementary. For example, product-related services such as maintenance rely on the technological skills that are closely related to the skills needed to design the product in the first place. A maintenance engineer designing the maintenance schedule of a machine would greatly benefit from having detailed documentation on the machine as well as access to the engineering team that designed the product. Thus, one may expect that the greater investment in product innovation will result in a better resource base for the service activities (Fang et al. 2008). On the other hand, productrelated services such as maintenance would deliver insights into how products behave in use or what new products and services would benefit customers. For example, a design engineer would greatly benefit from the service logs of the technicians who performed maintenance on the machine. Insights on the advantages and disadvantages of the current design of products could be readily used to design better-performing and easier-to-service products (Chesbrough 2011c; Lightfoot and Gebauer 2011).

The aforementioned examples illustrate the ease with which one may expect to achieve complementarity between product activities and product-related service activities. However, the provision of product-related services is unlikely to lead to ideas that depart from the product itself. This may mean that the scale of complementarity has limits and, in consequence, the marginal benefits of increasing the level of both activities will decrease. Furthermore, complementarity may find itself eclipsed in the competition for firm resources and capital that product innovation and servitization strategies are naturally subject to (Eggert et al. 2011; Gebauer 2011). Therefore, joint deployment of the product innovation and the product-oriented 
business model would likely result in a positive but saturating impact on knowledge and intellectual capital, characterized by an inverted U-shape relationship (Gebauer et al. 2008; Gremyr et al. 2010; Kinkel et al. 2011; Lightfoot and Gebauer 2011). Thus, the following hypothesis is proposed:

H3: The impact of the joint deployment (interaction) of product innovation and the productoriented business model on the accumulation of knowledge and intellectual capital is characterized by an inverted U-shape relationship.

Similar to the insights obtained from product-oriented service activities, the activities that underpin the customer-oriented business model may generate rich insights into underlying customer needs. Admittedly, this knowledge may often result in ideas that are unrelated to customers' existing products and that are more difficult to make use of. Thus, complementarity between innovation activities and customer-related service activities may be less pronounced and result in fewer economies of scope and complementarities between the product innovation and the customer-oriented service business model overall. However, since customer-related services are not bound to products but address customers' broader needs instead, it can be expected that the pool of knowledge and intellectual capital achievable through engagement in customerrelated services may result in an on-going stream of knowledge and ideas, without reaching saturation point. For example, by engaging in services such as financing or the buy-back of equipment, an industrial equipment manufacturer may learn that their customers struggle with logistics. The manufacturer in question could decide to build on those capabilities by developing a logistics business in its own right with potential growth opportunities. Consequently, the following hypothesis is proposed:

H4: The impact of the joint deployment (interaction) of product innovation and the customeroriented business model on the accumulation of knowledge and intellectual capital is positive and monotonous.

\section{Methodology}

\section{Sample and data collection}


To explore our research question, a representative sample of manufacturing firms with a service orientation was compiled by retrieving data from publicly available sources (Oliveira and Roth 2012a, 2012b). We first used the OSIRIS database ${ }^{4}$ to select listed companies with one hundred employees or more, based in developed countries and with primary SIC codes between 10 and 39, encompassing companies that were operating in industrial and manufacturing sectors (ranging from metal and coal mining to construction, machinery, and industrial equipment). Appendix A provides the full list of sectors and a detailed justification of the aforementioned criteria (Neely 2008). After eliminating firms that lacked relevant data and firms that, according to company descriptions, did not offer, at the very least, warranties or spare parts - our proxy for service orientation - we derived a sample of 133 servitizing firms. We obtained financial data for the 1999-2009 period from Datastream, and we collected the data related to servitization from annual reports and SIC filings (Dess and Robinson 1984; Michalisin 2001).

Using an established technique of expert panelists (MacCormack et al. 2001; Zott and Amit 2007), we trained a research assistant to rate, review and analyze the annual reports in relation to the target data. Initially, we focused on annual reports for each year between 2000 and 2008 . However, the differences between annual reports in consecutive years were relatively small, so we decided to sample annual reports biennially. In the same way that financial statistics are reported and analyzed at quarterly or yearly intervals and stock fluctuation analysis is based on daily intervals, our pilot study led us to the conclusion that a two-year interval was sufficient to capture the service portfolio's progression. As servitizing manufacturers tend to compound services (adding layer on layer to their service portfolios), we did not anticipate any bias. Hence, in the final data set, we only included data from annual reports for the years 2000, 2002, 2004, 2006 and 2008. The example of one firm from our sample and its development of services is provided in Table 1 for illustrative purposes.

\section{INSERT TABLE 1 ABOUT HERE}

We validated the rater's reliability by undertaking a thorough examination of her work. The lead author first examined the comprehensiveness of data collection and capture, by reviewing the information captured in the Excel file for five randomly selected companies. This quality check brought no issues to light concerning the rater's work, and the Excel template was 
accepted as a valid summary of the relevant annual report data. Furthermore, the lead author verified the content analysis of the quotations and the development of the service measures taken by reviewing all 572 observations. Only 31 observations were disputed, and they were subsequently corrected. The rater and the lead author were highly consistent in their assessments, with no disagreement in over $95 \%$ of cases.

\section{Measures}

Measures of efficiency and knowledge creation. EBIT Margin and Tobin's Q have been employed as our dependent variables. EBIT margin represents a ratio between EBIT and Total Sales, where EBIT represents the earnings of a company before interest payments and income taxes are deducted. It is calculated by taking the pre-tax income and adding back interest on debt and subtracting interest capitalized. In the servitization literature, it has been used as a measure of profitability and efficiency to assess the presence or absence of the service paradox (Gebauer et al. 2005; Neely 2008; Suarez et al. 2013; Visnjic Kastalli and Van Looy 2013).

In line with prior studies (Bharadwaj et al. 1999; Fang et al. 2008), we employ Tobin's Q to assess the intellectual capital and knowledge generated through servitization. It captures increases in a firm's market value due to intangible assets (Fang et al. 2008). Following Fang et al. (2008) and Chung and Pruitt (1994), we calculate Tobin's Q as the ratio between market capitalization and debt, on the one hand, and the book value of total assets, on the other. Tobin's Q has been used in other studies as the indicator of market performance, and we have also considered this interpretation of the indicator in our discussion (e.g. Benner and Veloso 2008).

Measures for the chosen business model. To derive our three business models (product-only model, product-oriented model, and customer-oriented model), we used dummy variables to operationalize the stages of servitization described in the hypotheses. The business models are coded as follows:

- Product-only business model: No services are mentioned in the annual report. A company offers no services to its customers, apart from warranties or spare parts.

- Product-oriented business model: A company offers one or more services - such as supplies, components for its products and (technical) documentation about its products, 
repair, maintenance, upgrades, construction, installation, logistics, and/or overhaul services (a full list of services is provided in Appendix A).

- Customer-oriented business model: In the product-oriented business model, productrelated services listed above are increasingly complemented with customer-related services: customer support, financial services, training, education, consulting, project management, turnkey solutions, storage, and day-to-day operations.

Product innovation and its interaction with the business model. Furthermore, we used the $\mathrm{R} \& \mathrm{D} /$ Sales ratio, or the extent of $\mathrm{R} \& \mathrm{D}$ intensity, as a measure of product innovation. Investment in $\mathrm{R} \& \mathrm{D}$ activities has been used extensively as the indicator for product innovation (Chen and Miller 2007; Gaba and Bhattacharya 2012) and, given the manufacturing industry sample and general tendency for service innovations to be developed outside $R \& D$, we decided it safe to assume that R\&D captures investment in product innovations predominantly (Becker and Dietz 2004; Hipp and Grupp 2005). We used the product of R\&D/Sales ratio and the chosen business model (product-only, product-oriented, or customer-oriented) to measure the interaction or complementarity between the chosen business model and the product innovation (Cassiman and Veugelers 2006; Novak and Eppinger 2001).

Number of services. In addition to the type of service portfolio chosen, a company may also decide on the number of services it should offer. For example, a firm may decide to offer only total solutions, or to offer individual services such as spares and repairs in parallel with total solutions. The number of services captures this decision with respect to the size of the service portfolio. Since prior studies have shown that it may have a significant negative impact on profit performance (Neely 2008), we include it as a control variable.

Other controls. Since servitization can be seen as a particular type of differentiation strategy (Bowen et al. 1989; Gebauer et al. 2005), we have controlled for the level of product diversification as well as geographical diversification. Product diversification has been calculated using a Herfindahl Index of different product market segments (Chakrabarti et al. 2007), with geographical diversification measured as a percentage of foreign sales. We control for the size of the firm using the log of total assets. To control for yearly cycles and the effects of annual price increases, we include time dummies. Table 2 provides summary statistics and the correlation coefficients of the relevant variables. 


\section{Empirical analysis and results}

To test our hypotheses, we performed panel data analysis with fixed effects. The fixed-effect models include dummy variables for each company, thereby 'specifying an estimable conditional mean' and addressing biased and inconsistent parameter estimates (Wooldridge 2002, 2006). We introduce fixed effects to control for time-invariant, unobserved heterogeneity among companies (Wooldridge 2002, 2006). Prior longitudinal studies on servitization have opted for fixed effects to control for differences in managerial cognitions in manufacturing companies in relation to services or for cultural differences in service adoption and acceptance (Visnjic Kastalli and Van Looy 2013).

In testing Hypotheses 1 and 2, independent variables are introduced with a one-year lag to account for the lag between changes in strategy and the effect on profitability. In Hypotheses 3 and 4, we expect the interaction between investment in product innovation and servitization to take at least three years to generate additional knowledge and intellectual capital, and we account for this by introducing the three-year lag. The decision to resort to three-year lags was made after considering the fact that an average patent application is awarded only after three years (the US Patent Authority averaged 34.6 months in 2009). Together with the fixed effects, lags also help to ensure that causality is properly specified and that the threat of endogeneity is minimized. The models are specified below:

\section{All independent in $t-1$}

Model 1: EBIT Margin $=\mathrm{a}+\mathrm{b}^{*}$ Product-oriented BM $+\mathrm{c}^{*}$ Customer-oriented BM $+\mathrm{d}^{*}$ $\mathrm{R} \& \mathrm{D} /$ Sales $+\mathrm{e}^{*}$ Product-oriented BM*R\&D/Sales $+\mathrm{f} *$ Customer-oriented BM*R\&D/Sales $+\mathrm{g}$ $*$ Number of services $+\mathrm{h} *$ Geographical diversification ratio $+\mathrm{i} *$ Product market diversification $\mathrm{HI}+\mathrm{j} *$ dummy $2003+\mathrm{k} *$ dummy $2005+\mathrm{l} *$ dummy $2007+\mathrm{m} *$ dummy $2009+\mathrm{e}$

\section{All the same as above, but independent in $t-3$}

Model 2: EBIT Margin $=\mathrm{a}+\mathrm{b}^{*}$ Product-oriented BM $+\mathrm{c}^{*}$ Product-oriented BM Squared $+\mathrm{d}^{*}$ Customer-oriented BM $+\mathrm{e}^{*} \mathrm{R} \& \mathrm{D} /$ Sales $+\mathrm{f}^{*}$ Product-oriented BM*R\&D/Sales $+\mathrm{g} *$ Customeroriented $B M^{*} R \& D /$ Sales $+h *$ Number of services $+i^{*}$ Geographical diversification ratio $+\mathrm{j} *$ Product market diversification $\mathrm{HI}+\mathrm{k} *$ dummy $2003+1 *$ dummy $2005+\mathrm{m} *$ dummy $2007+\mathrm{n} *$ dummy $2009+\mathrm{e}$ 
We performed several robustness checks before accepting the results of the analysis. First, the calculation of the VIF factor has shown that the total-assets control causes some multicollinearity issues in both models. Given this effect, we re-specified the models without the total-assets control; the results did not change, and the VIF factor fell below 10 for all variables apart from the interacted ones (as expected). Subsequently, we decided to accept the reformulated model. We have excluded the concern of heteroskedasticity using the Modified Wald test for group-wise heteroskedasticity in fixed-effect regression models (Green 2008). The test for serial correlation by Wooldridge (2002) confirmed our concerns over the presence of serial correlation, which led us to adopt correlation-robust standard errors.

Model 1a, reported in Table 3 (overall $\mathrm{R}^{2}=.219$ ), summarizes our results with regard to $\mathrm{H} 1$ and $\mathrm{H} 2$. $\mathrm{H} 1 / \mathrm{H} 2$ propose that both models, the product-oriented and the customer-oriented business models, will have a significantly positive impact on a company's efficiency measured by the EBIT Margin in the following year, as compared to the product-only business model. Results confirm that the product-oriented business model $(\beta=.080 ; p=.020)$ and the customeroriented model $(\beta=.105 ; \mathrm{p}=.007)$ in $\mathrm{t}-1$ have a significant positive impact on a company's EBIT Margin in $\mathrm{t}$ and that the customer-oriented model has even greater impact, thus confirming $\mathrm{H} 1$ and H2. At the same time, Model M1a suggests that the deployment of any of the two service business models, when combined with product innovation, leads to a negative impact on efficiency. More specifically, the interaction between the R\&D share of sales and the productoriented business model in $\mathrm{t}-1(\beta=-.015 ; \mathrm{p}=.000)$ as well as the interaction between the R\&D share of sales and the customer-oriented model $(\beta=-.015 ; \mathrm{p}=.000)$ both have a significantly negative impact on a company's EBIT Margin in t. Finally, an important insight from Model $\mathrm{M} 1 \mathrm{a}$ is that the increase in the number of services in t-1 leads to a decrease in the EBIT Margin in $\mathrm{t}$, as suggested by prior studies (Neely 2008).

------ INSERT TABLE 3 ABOUT HERE ------

In $\mathrm{H} 3$, we proposed that the interaction between the product-oriented business model and product innovation ( $R \& D /$ sales) will have a positive impact on the accumulation of knowledge and intellectual capital (Tobin's Q) after three years. Results reported in Model M2b (overall $\mathrm{R}^{2}$ $=.245$ ) indicate that the interaction effect from $\mathrm{t}-3$ has a significant positive impact on a 
company's Tobin's $Q(\beta=.111 ; \mathrm{p}=.042)$ in t. At the same time, the significant negative effect of the quadratic term of the interaction effect $(\beta=-.006 ; p=.037)$ indicates that the effect of the interaction is not constant but reaches a saturation point and, then, decreases at higher levels of R\&D expenditure.

In H4, we proposed a positive linear effect of the interaction between the deployment of the customer-oriented business model and the deployment of product innovation (R\&D/sales) in t-3 on the accumulation of knowledge and intellectual capital (Tobin's Q) in t. Results indicate that the interaction effect was significant $(\beta=.027 ; p=.000)$. Thus, we confirm H4. Nevertheless, Model M2b also suggests that, if deployed in isolation from product innovation, both the product-oriented business model $(\beta=-.543 ; \mathrm{p}=.022)$ and the customer-oriented business model $(\beta=-.471 ; p=.039)$ have negative impacts on the accumulation of knowledge and intellectual capital (Tobin's Q).

\section{Discussion}

Our research was guided by the question: "Does the concurrent adoption of service business models (servitization) and investment in product innovation result in significant performance benefits?". In short, our results suggest that the decision to servitize cannot merely be considered a dichotomous, 'yes-or-no' choice. Manufacturing firms have to decide whether to deploy product innovation and servitization together and which (product or service) business model to adopt, and they must consider the impact of these decisions in both the short and the long term.

It seems that the changing performance implications of the relationship between servitization and product innovation over the short versus the long term should be a central concern of the manufacturer. When considering only the short-term impact on profitability, a manufacturer may be convinced of the need to focus on one of the two: servitization or product innovation. Deployed independently, both seem to result in performance improvement in the subsequent year whereas, deployed jointly, they result in a decrease in performance in the subsequent year. This substitution effect is consistent with previous studies that suggest that servitization and product innovation compete for the same resources (Eggert et al. 2011; Gebauer 2011). For example, a firm may need to make specific service investments and, at the same time, continue to spend 
resources on product innovation (Visnjic Kastalli and Van Looy 2013). Given that the returns on both may be delayed, joint deployment can put a strain on resources.

Joint deployment may also result in an initial increase in coordination costs. For example, a company may need to hire additional managers to oversee the two strategy deployments (Oliva and Kallenberg 2003), and companies may need to engage in corporate restructuring (Neu and Brown 2005, 2008). Indeed, these costs would be incurred in the short run while their benefits particularly the knowledge gain from joint deployment - would likely require more time. For example, it would take time before products could be designed to facilitate easier service; the service sales force and technicians would need to be trained and incentivized to collect and transmit information to the $\mathrm{R} \& \mathrm{D}$ department on the products in use, before engineers could use this information to design better products.

When we considered the impact on the creation of knowledge and intellectual capital after three years, we saw that the joint deployment of service business models and product innovation resulted in higher knowledge and intellectual capital gains than the product-only business model. As previous literature indicates, the positive value-creating loop between products and services will not only create revenues but also knowledge (Visnjic Kastalli and Van Looy 2013). Indeed, consistent with the predictions of business model literature (Chesbrough 2011b), servitizing may lead to open service innovation, where insights collected from the service provision and customer contact are used in the R\&D unit to make better products. Moreover, not only can firms design new products for increased user experience that customers are willing to pay for, but these products would be designed for better serviceability. For example, after engaging in servicing a compressor, one manufacturer that we know of realized that it needed to redesign the equipment for better cleaning access.

Thus, while product innovation and service business model innovation together results in short-term sacrifices, this may be the only long-term choice for some companies. Results suggest that manufacturing firms that decide to adopt only servitization or product innovation are running the risk of destroying value, as the independent deployment of either strategy would result in a decrease in knowledge and intellectual capital, as measured by Tobin's Q. A good example of this situation would be a company that generates revenues by offering a performance-based contract in the form of product uptime, such as Rolls-Royce (Neely 2008). Since Rolls-Royce is paid only for the availability of its airplane engines in a form of price per 
$\mathrm{KW} / \mathrm{h}$, any improvement in the performance of its products and subsequent improvement in the product availability represents a direct improvement in the firm's performance.

Besides deciding on whether and when to innovate products and servitize, managers need to choose between the two service business models. Manufacturers may decide either to limit their aspirations to moderate levels of servitization with a product-focused service offering (e.g. maintenance) or to focus fully on complete service solutions that couple product-related services with knowledge-intensive services (e.g. consulting). On a standalone basis, the customeroriented business model seems to be more profitable while, taking into account the interaction effect on the product innovation, the negative effects seem to be identical for both serviceoriented business models. On the other hand, the product-oriented business model, when paired with a product innovation, results in a steep increase in knowledge generation for low levels of $\mathrm{R} \& \mathrm{D}^{5}$. Hence, a firm with low $\mathrm{R} \& \mathrm{D}$ investments may find it more beneficial to adopt the product-oriented business model, since gains in knowledge creation accrue quite rapidly with this model.

On the other hand, manufacturers that offer more complete service offerings containing knowledge-intensive service components - such as consulting or training - may achieve superior margins at the higher levels of product innovativeness. Even though the complementarity between the customer-oriented business model and the product innovation may result in a more modest increase in knowledge capital than the product-oriented business model, this increase will persist and will not decrease at high levels of product investment, a phenomenon that characterizes the product-oriented business model. Hence, for those companies that are already 'strong product innovators', the customer-oriented business model may help in reaching new frontiers of knowledge over time. 'Product-innovation laggards' may decide to start with the product-oriented business model and then switch to the customer-oriented business model, once a high level of investment in product development has been achieved.

\section{Conclusion}

This research was undertaken to provide a deeper analysis of the performance implications of service business model innovations (servitization) and their interplay with product innovation. For the aspiring product-service provider, we reveal several strategic variables that need to be considered over short- and long-term horizons. To begin with, manufacturers are advised to 
consider product innovation and servitization as 'long-term games' and balance short-term substitution effects against long-term complementarity. A manufacturing firm may wish to maintain their investments in product innovation whilst, at the same time, ramping up investment in their service business model. While this may put constraints on their profitability in the short term, it seems to produce results in terms of accumulated knowledge in the long term. Furthermore, manufacturing firms need to decide how to deploy servitization, and which service business model to adopt and when. The customer-oriented business model seems to offer a positive linear impact on knowledge and market performance, but it needs to be combined with high R\&D intensity for strong effects to accrue. On the other hand, firms that are less R\&D intensive may want to start with the product-oriented business model, where they can reap strong complementarities early on and then change to the customer-oriented business model as they increase their R\&D intensity. This change from the product-oriented business model to the customer-oriented business model has indeed been the prevalent choice of manufacturing firms in our sample.

We combine theoretical frameworks from two theories, the complementarity perspective (Milgrom and Roberts 1995; Siggelkow and Levinthal 2003) and the demand perspective on value creation (Priem 2007; Ye et al. 2012) to achieve a precise understanding of the different sources of value that influence the performance effects of the complex relationship between product innovation and servitization. Our work adds to an emerging literature on servitization by testing separately the performance implications of the product-oriented and the customeroriented business models (Spring and Araujo 2009; Zott and Amit 2007, Raja et al. 2013). Our research is one of the first studies to empirically test the hypothesized knowledge loop between service business model innovations and product innovation, and also provides empirical backing for open-service innovation (Chesbrough 2011a).

Moreover, we contribute to the broader innovation literature by offering the first empirical backing for the hypothesized impact of complementary services on the value appropriability of product innovation (Teece 1986). We also contribute to the complementarity perspective (Ennen and Richter 2010; Cassiman 2006) by hypothesizing how complementarity emerges and by subsequently testing those assertions. Finally, through the demand perspective on value creation and the user-sided economies of scope, this study joins previous scholars (Raja et al. 2013; Priem et al. 2012) in an effort to incorporate demand-side issues into the scholarship of innovation 
management. We contribute to the demand perspective on value creation by finding empirical support for demand-based economies of scope as a value driver for servitization (Ye et al. 2012). Besides being the first study to use this theoretical lens on the value creation stemming from servitization strategy and service business model innovations, we are amongst the first to apply this theory to a Business-to-Business context (Priem 2007).

Nevertheless, our research has several limitations that need to be taken into account when interpreting our results. We are confined by a relatively small data set, and our core service variables are derived from the qualitative assessment of public data rather than from hard, quantitative evidence. Introducing certain refinements could further improve the efficacy of our models. Firstly, the extent of servitization would help to put other variables in perspective. Better control variables for industry-level performance are also warranted. Second, the measures we used for the service business models could be further sharpened. For example, the customeroriented business model can be seen as a group of business models, which vary, particularly in terms of whether the underlying services are bundled in an integrated solution or whether they are provided separately. The success of particular business models where the manufacturer outsources certain aspects of service provision whilst retaining the remainder should also be considered (Cohen et al. 2006). Third, the measure of product innovation (R\&D/sales ratio) is quite imprecise. For instance, it does not capture the emerging efforts of companies to source innovation outside the boundaries of the firm. Finally, there may be an undetected self-selection bias in the data. The sample only captures companies that chose to publish their servitization efforts in 2008. It is conceivable that some companies may have chosen not to publish their servitization efforts, for various reasons. Although utilizing data from annual reports would appear to be an appropriate method for exploring our research question, it should be noted that this specific issue may have confounded our results.

Once further quantitative data on service strategy is made available, future studies could add value by tackling these questions with greater precision or by replicating the analysis on a larger data set and in different industrial settings such as the software sector (Suarez et al. 2013). In particular, longer time spans would help to more directly test predictions concerning the complementarity of product innovation and service business models and their hypothesized impact on higher profitability for the innovators (Teece 1986). For the time being, we have to be content with capturing this complementarity on the level of the knowledge gains and superior 
market performance before these become discernible in the accounting performance (Zott and Amit 2007). Some preliminary tests that we carried out to examine the impact of service business models on profit performance after three years already show a positive impact of the interaction between the customer-oriented business model and the EBIT Margin, but the impact of the product-oriented business model on the EBIT Margin is not (yet) visible. Furthermore, disentangling the causality between servitization, open service innovation and product innovation could well be another promising avenue for future research.

\section{References}

Amit, R. and C. Zott. 2001. Value Creation in e-Business. Strategic Management Journal 22 (67): 493-520.

Amit, R. and C. Zott. 2012. Creating Value through Business Model Innovation. MIT Sloan Management Review 53 (3): 41-49.

Andries, P. and D. Faems. 2013. Patenting Activities and Firm Performance: Does Firm Size Matter? Journal of Product Innovation Management 30 (6): 1089-1098.

Baines, T. and H. W. Lightfoot. 2013. Servitization of the Manufacturing Firm: Exploring the Operations Practices and Technologies that Deliver Advanced Services. International Journal of Operations \& Production Management 34 (1): 2-35.

Barney, J. 1991. Firm Resources and Sustained Competitive Advantage. Journal of Management 17 (1): 99-120.

Becker, W. and J. Dietz. 2004. R\&D Cooperation and Innovation Activities of Firms: Evidence for the German Manufacturing Industry. Research Policy 33 (2): 209-223.

Benner, M. J. and F. M. Veloso. 2008. ISO 9000 Practices and Financial Performance: A Technology Coherence Perspective. Journal of Operations Management 26 (5): 611-629.

Bharadwaj, A. S., S. G. Bharadwaj, and B. R. Konsynski. 1999. Information Technology Effects on Firm Performance as Measured by Tobin's Q. Management Science 45 (7): 1008-1024.

Blindenbach-Driessen, F. and J. van den Ende. 2014. The Locus of Innovation: The Effect of a Separate Innovation Unit on Exploration, Exploitation, and Ambidexterity in Manufacturing and Service Firms. Journal of Product Innovation Management Early View. 
Bowen, D., C. Siehl, and B. Schneider. 1989. A Framework for Analyzing Customer Service Orientations in Manufacturing. Academy of Management Review 14 (1): 75-95.

Caerteling, J. S., J. I. M. Halman, and A. G. Doree. 2008. Technology Commercialization in Road Infrastructure: How Government Affects the Variation and Appropriability of Technology. Journal of Product Innovation Management 25 (2): 143-161.

Canton, I. D. 1984. Learning to Love the Service Economy. Harvard Business Review 62 (3): 89-97.

Carlborg, P., D. Kindström, and C. Kowalkowski. 2014. The Evolution of Service Innovation Research: A Critical Review and Synthesis. Service Industries Journal 5 (5): 373-398.

Cassiman, B. and R. Veugelers. 2006. In Search of Complementarity in Innovation Strategy: Internal R\&D and External Knowledge Acquisition. Management Science 52 (1): 68-82.

Chakrabarti, A., K. Singh, and I. Mahmood. 2007. Diversification and Performance: Evidence from East Asian Firms. Strategic Management Journal 28 (2): 101-120.

Chase, R. 1981. The Customer Contact Approach to Services: Theoretical Bases and Practical Extensions. Operations Research 29 (4): 698-706.

Chen, W.-R. and K. D. Miller. 2007. Situational and Institutional Determinants of Firms' R\&D Search Intensity. Strategic Management Journal 28 (4): 369-381.

Chesbrough, H. 2010. Business Model Innovation: Opportunities and Barriers. Long Range Planning 43 (2-3): 354-363.

Chesbrough, H. 2011a. Bringing Open Innovation to Services. MIT Sloan Management Review 52 (2): 85-90.

Chesbrough, H. 2011b. The Case for Open Services Innovation: The Commodity Trap. California Management Review 53 (3): 5-20.

Chesbrough, H. 2011c. Open Services Innovation: Rethinking Your Business to Grow and Compete in a New Era. San Francisco, CA: Jossey-Bass.

Chesbrough, H. 2012. Open Innovation Where We've Been and Where We're Going. ResearchTechnology Management 55 (4): 20-27.

Chesbrough, H. and R. S. Rosenbloom. 2002. The Role of the Business Model in Capturing Value from Innovation: Evidence from Xerox Corporation's Technology Spin-Off Companies. Industrial and Corporate Change 11 (3): 529-555. 
Chung, K. H. and S. W. Pruitt. 1994. A Simple Approximation of Tobins-Q. Financial Management 23 (3): 70-74.

Cohen, M. A., C. Cull, H. L. Lee, and D. Willen. 2000. Saturn's Supply-Chain Innovation: High Value in After-Sales Service. MIT Sloan Management Review 41 (4): 93-103.

Cohen, M. A., N. Agrawal, and V. Agrawal. 2006. Winning in the Aftermarket. Harvard Business Review 84 (5): 129-138.

Cottrell T. and B. R. Nault. 2004. Product Variety and Firm Survival in the Microcomputer Software Industry. Strategic Management Journal 25 (10): 1005-1025.

Cusumano, M. A. 2004. The Business of Software: What Every Manager, Programmer, and Entrepreneur Must Know to Thrive and Survive in Good Times and Bad. New York: Free Press.

Cusumano, M. A., S. J. Kahl, and F. F. Suarez. 2014. Services, industry evolution, and the competitive strategies of product firms. Strategic Management Journal DOI: 10.1002/smj.2235

Dahlander, L. and M. W. Wallin. 2006. A Man on the Inside: Unlocking Communities as Complementary Assets. Research Policy 35 (8): 1243-1259.

Dedrick, J., K. L. Kraemer, and G. Linden. 2010. Who Profits from Innovation in Global Value Chains?: A Study of the iPod and Notebook PCs. Industrial and Corporate Change 19 (1): 81-116.

Dess, G. G. and R. B. Robinson. 1984. Measuring Organizational Performance in the Absence of Objective Measures: The Case of the Privately-Held Firm and Conglomerate Business Unit. Strategic Management Journal 5 (3): 265-273.

Desyllas, P. and M. Sako. 2013. Profiting from Business Model Innovation: Evidence from Payas-You-Drive Auto Insurance. Research Policy 42 (1): 101-116.

Eggert, A., J. Hogreve, W. Ulaga, and E. Muenkhoff. 2011. Industrial Services, Product Innovations, and Firm Profitability: A Multiple-Group Latent Growth Curve Analysis. Industrial Marketing Management 40 (5): 661-670.

Eggert, A., J. Hogreve, W. Ulaga, and E. Muenkhoff. 2014. Revenue and Profit Implications of Industrial Service Strategies. Journal of Service Research 17 (1): 23-39. 
Ennen, E. and A. Richter. 2010. The Whole Is More than the Sum of Its Parts - or Is It? A Review of the Empirical Literature on Complementarities in Organizations. Journal of Management 36 (1): 207-233.

Fang, E., R. Palmatier, and J. Steenkamp. 2008. Effect of Service Transition Strategies on Firm Value. Journal of Marketing 72 (5): 1-14.

Gaba, V. and S. Bhattacharya. 2012. Aspirations, Innovation, and Corporate Venture Capital: A Behavioral Perspective. Strategic Entrepreneurship Journal 6 (2): 178-199.

Gambardella, A. and A. M. McGahan. 2010. Business-Model Innovation: General Purpose Technologies and Their Implications for Industry Structure. Long Range Planning 43 (2-3): 262-271.

Gebauer, H. 2008. Identifying Service Strategies in Product Manufacturing Companies by Exploring Environment-Strategy Configurations. Industrial Marketing Management 37 (3): 278-291.

Gebauer, H. 2011. Exploring the Contribution of Management Innovation to the Evolution of Dynamic Capabilities. Industrial Marketing Management 40 (8): 1238-1250.

Gebauer, H., E. Fleisch and T. Friedli. 2005. Overcoming the Service Paradox in Manufacturing Companies. European Management Journal 23 (1): 14-26.

Gebauer, H., G. J. Ren, A. Valtakoski, and J. Reynoso. 2012. Service-Driven Manufacturing Provision, Evolution and Financial Impact of Services in Industrial Firms. Journal of Service Management 23 (1): 120-136.

Gebauer, H., R. Krempl, E. Fleisch, and T. Friedli. 2008. Innovation of Product-Related Services. Managing Service Quality 18 (4): 387-404.

Green, W., Econometric Analysis. Prentice Hall. Sixth edition 2008. Econometric Analysis. Upper Saddle River, NJ: Prentice Hall.

Gremyr, I., N. Lofberg, and L. Witell. 2010. Service Innovations in Manufacturing Firms. Managing Service Quality 20 (2): 161-175.

Guajardo, J., M. Cohen, S. Netessine, and S. Kim. 2011. Impact of Performance-Based Contracting on Product Reliability: An Empirical Analysis. Management Science 58 (5): 961-979.

Helfat, C. E. 1994. Firm-Specificity in Corporate Applied R\&D. Organization Science 5 (2): 173-184. 
Helfat, C. E. 1997. Know-How and Asset Complementarity and Dynamic Capability Accumulation: The Case of R\&D. Strategic Management Journal 18 (5): 339-360. Hipp, C. and H. Grupp. 2005. Innovation in the Service Sector: The Demand for ServiceSpecific Innovation Measurement Concepts and Typologies. Research Policy 34 (4): 517535.

Jacobs, M., C. Droge, S. K. Vickery, and R. Calantone. 2011. Product and Process Modularity's Effects on Manufacturing Agility and Firm Growth Performance. Journal of Product Innovation Management 28 (1): 123-137.

James, S. D., M. J. Leiblein, and S. H. Lu. 2013. How Firms Capture Value from Their Innovations. Journal of Management 39 (5): 1123-1155.

Kinkel, S., E. Kirner, H. Armbruster, and A. Jager. 2011. Relevance and Innovation of Production-Related Services in Manufacturing Industry. International Journal of Technology Management 55 (3-4): 263-273.

Lele, M. M. 1986. How Service Needs Influence Product Strategy. Sloan Management Review 28 (1): 63-70.

Leten, B., R. Belderbos, and B. Van Looy. 2007. Technological Diversification, Coherence, and Performance of Firms. Journal of Product Innovation Management 24 (6): 567-579.

Lightfoot, H. W. and H. Gebauer. 2011. Exploring the Alignment between Service Strategy and Service Innovation. Journal of Service Management 22 (5): 664-683.

MacCormack, A., R. Verganti, and M. Iansiti. 2001. Developing Products on "Internet Time": The Anatomy of a Flexible Development Process. Management Science 47 (1): 133-150.

Martinez, V., M. Bastl, J. Kingston, and E. Evans. 2010. Challenges in Transforming Manufacturing Organisations into Product-Service Providers. Journal of Manufacturing Technology Management 21 (4): 449-469.

Mathieu, V. 2001. Service Strategies within the Manufacturing Sector: Benefits, Costs and Partnership. International Journal of Service Industry Management 12 (5): 451-475.

Michalisin, M. D. 2001. Validity of Annual Report Assertions About Innovativeness: An Empirical Investigation. Journal of Business Research 53 (3): 151-161.

Milgrom, P. and J. Roberts. 1995. Complementarities and Fit Strategy, Structure, and Organizational Change in Manufacturing. Journal of Accounting and Economics 19 (2-3): 179-208. 
Nayyar, P. 1993. Stock-Market Reactions to Related Diversification Moves by Service Firms Seeking Benefits from Information Asymmetry and Economies of Scope. Strategic Management Journal 14 (8): 569-591.

Neely, A. 2008. Exploring the Financial Consequences of the Servitization of Manufacturing. Operations Management Research 1 (2): 103-118.

Neu, W. A. and S. W. Brown. 2005. Forming Successful Business-to-Business Services in Goods-Dominant Firms. Journal of Service Research 8 (1): 3-17.

Neu, W. A. and S. W. Brown. 2008. Manufacturers Forming Successful Complex Business Services: Designing an Organization to Fit the Market. International Journal of Service Industry Management 19 (2): 232-251.

Novak, S. and S. D. Eppinger. 2001. Sourcing by Design: Product Complexity and the Supply Chain. Management Science 47 (1): 189-204.

Oliva, R. and R. Kallenberg. 2003. Managing the Transition from Products to Services. International Journal of Service Industry Management 14 (2): 160-172.

Oliveira, P. and A. V. Roth. 2012a. The Influence of Service Orientation on B2B e-Service Capabilities: An Empirical Investigation. Production and Operations Management 21 (3): 423-443.

Oliveira, P. and A. V. Roth. 2012b. Service Orientation: The Derivation of Underlying Constructs and Measures. International Journal of Operations \& Production Management 32(1-2): 156-190.

Ostrom, A. L., M. J. Bitner, S. W. Brown, K. A. Burkhard, M. Goul, V. Smith-Daniels, H. Demirkan, and E. Rabinovich. 2010. Moving Forward and Making a Difference: Research Priorities for the Science of Service. Journal of Service Research 13 (1): 4-36.

Pae, J. H. and J. S. Hyun. 2002. The Impact of Technology Advancement Strategies on Consumers' Patronage Decisions. Journal of Product Innovation Management 19 (5): 375383.

Priem, R. L. 2007. A Consumer Perspective on Value Creation. Academy of Management Review 32 (1): 219-235.

Priem, R. L., S. L. Li, and J. C. Carr. 2012. Insights and New Directions from Demand-Side Approaches to Technology Innovation, Entrepreneurship, and Strategic Management Research. Journal of Management 38 (1): 346-374. 
Quinn, J. and C. Gagnon. 1986. Will Services Follow Manufacturing into Decline. Harvard Business Review 64 (6): 95-103.

Raddats, C. and C. Easingwood. 2010. Services Growth Options for B2B Product-Centric Businesses. Industrial Marketing Management 39 (8): 1334-1345.

Raja J. Z., D. Bourne, K. Goffin, M. Çakkol, and V. Martinez. 2013. Achieving Customer Satisfaction through Integrated Products and Services: An Exploratory Study. Journal of Product Innovation Management 30 (6): 1128-1144.

Sahay, A. and D. Riley. 2003. The Role of Resource Access, Market Considerations, and the Nature of Innovation in Pursuit of Standards in the New Product Development Process. Journal of Product Innovation Management 20 (5): 338-355.

Schumpeter, J. A. 1942. Capitalism, Socialism and Democracy. New York: Harper.

Siggelkow, N. and D. A. Levinthal. 2003. Temporarily Divide to Conquer: Centralized, Decentralized, and Reintegrated Organizational Approaches to Exploration and Adaptation. Organization Science 14 (6): 650-669.

Snihur, Y. and C. Zott. 2014. Legitimacy without Imitation: How to Achieve Robust Business Model Innovation. Working paper. IESE Business School.

Sorescu, A. B., R. K. Chandy, and J. C. Prabhu. 2003. Sources and Financial Consequences of Radical Innovation: Insights from Pharmaceuticals. Journal of Marketing 67 (4): 82-102. Spohrer, J. and P. P. Maglio. 2008. The Emergence of Service Science: Toward Systematic Service Innovations to Accelerate Co-Creation of Value. Production and Operations Management 17 (3): 238-246.

Spring, M. and L. Araujo. 2009. Service, Services and Products: Rethinking Operations Strategy. International Journal of Operations \& Production Management 29(5): 444-467.

Suarez, F. F., M. A. Cusumano, and S. J. Kahl. 2013. Services and the Business Models of Product Firms: An Empirical Analysis of the Software Industry. Management Science 59 (2): 420-435.

Teece, D. 1982. Towards an Economic Theory of the Multiproduct Firm. Journal of Economic Behavior \& Organization 3(1): 39-63.

Teece, D. J. 1986. Profiting from Technological Innovation: Implications for Integration, Collaboration, Licensing and Public Policy. Research Policy 15 (6): 285-305. 
Teece, D. J. 2010. Business Models, Business Strategy and Innovation. Long Range Planning 43 (2-3): 172-194.

Thoma, J. and K. Bizer. 2013. To Protect or Not to Protect? Modes of Appropriability in the Small Enterprise Sector. Research Policy 42 (1): 35-49.

Tripsas, M. 1997. Unraveling the Process of Creative Destruction: Complementary Assets and Incumbent Survival in the Typesetter Industry. Strategic Management Journal 18 (S1): 119142.

Turunen, T. 2011. Users as a Development Driver in Manufacturing: the Case of 'Reverse' Servitization. In User-Based Innovation in Services, ed. J. Sundbo, and M. Toivonen, 177199. Cheltenham, UK: Edward Elgar.

Van den Ende, J., F. Jaspers, and S. A. Rijsdijk. 2013. Should System Firms Develop Complementary Products? A Dynamic Model and an Empirical Test. Journal of Product Innovation Management 30 (6): 1178-1198.

Van Looy, B., P. Gemmel, and R. Van Dierdonck . 2003. Services Management: An Integrated Approach. Harlow, UK: Pearson Education.

Vandermerwe, S. and J. Rada. 1988. Servitization of Business: Adding Value by Adding Services. European Management Journal 6 (4): 314-324.

Visnjic Kastalli, I. and B. Van Looy. 2013. Servitization: Disentangling the Impact of Service Business Model Innovation on Manufacturing Firm Performance. Journal of Operations Management 31 (4): 169-180.

Visnjic Kastalli, I., B. Van Looy, and A. Neely. 2013. Steering Manufacturing Firms towards Service Business Model Innovation. California Management Review 56 (1): 100-123.

Winter, S. G. 2006. The Logic of Appropriability: From Schumpeter to Arrow to Teece. Research Policy 35 (8): 1100-1106.

Wise, R. and P. Baumgartner. 1999. Go Downstream: the New Profit Imperative in Manufacturing. Harvard Business Review 77 (5): 133-141.

Wooldridge, J. 2002. Econometric Analysis of Cross Section and Panel Data. Cambridge, Massachusetts: The MIT Press.

Wooldridge, J. 2006. Introductory Econometrics: A Modern Approach. Mason, Ohio: ThomsonSouth Western. 
Ye, G., R. L. Priem, and A. A. Alshwer. 2012. Achieving Demand-Side Synergy from Strategic

Diversification: How Combining Mundane Assets Can Leverage Consumer Utilities.

Organization Science 23 (1): 207-224.

Zott, C. and R. Amit. 2007. Business Model Design and the Performance of Entrepreneurial

Firms. Organization Science 18 (2): 181-199.

Zott, C. and Amit, R. 2008. The Fit between Product Market Strategy and Business Model:

Implications for Firm Performance. Strategic Management Journal 29 (1): 1-26.

Zott, C., R. Amit, and L. Massa. 2011. The Business Model: Recent Developments and Future

Research. Journal of Management 37 (4): 1019-1042.

\footnotetext{
${ }^{1}$ Following Amit and Zott (2012), we define 'business model' as a system of interconnected and interdependent activities that determines the way the company 'does business' with its customers, partners and vendors.

${ }^{2}$ Several studies cover the role of strong protection mechanisms, such as patents (Andries and Faems 2013; James et al. 2013), secrecy, (Thoma and Bizer 2013), standards (Sahay and Riley 2003), governmental protection (Caerteling et al. 2008), network effects, communities and switching costs (Dahlander and Wallin 2006; Pae and Hyun 2002).

${ }^{3}$ Subsequent literature provided empirical support for the complementary role of manufacturing (Jacobs et al. 2011), marketing capabilities (Sorescu et al. 2003), complementary products (Dedrick et al. 2010; van den Ende et al. 2013) and complementary knowledge (Helfat 1997) in the process of value capture.

${ }^{4}$ The OSIRIS database, provided by the Bureau van Dijk, represents one of the key sources on financials, ownership, subsidiaries, ratings, earnings estimates, stock data, and additional industry codes (Dow Jones Global Indexes); it has been helpful in selecting companies based on their primary SIC code.

${ }^{5}$ Given that product development investment is measured by the $\mathrm{R} \& \mathrm{D} / \mathrm{Sales}$ ratio and the productoriented business model is represented by a simple dummy variable, the interaction between the two is basically equal to the $\mathrm{R} \& \mathrm{D} /$ Sales ratio.
} 


\section{FIGURES AND TABLES}

Table 1: Illustration of business model data for one firm

\begin{tabular}{|c|c|c|c|c|c|c|c|c|c|c|}
\hline Year & 2000 & 2001 & 2002 & 2003 & 2004 & 2005 & 2006 & 2007 & 2008 & 2009 \\
\hline Tobin's Q & 1.47 & 1.25 & 1.31 & 1.70 & 2.41 & 3.12 & 3.18 & 2.83 & 1.16 & 1.73 \\
\hline $\begin{array}{c}\text { EBIT } \\
\text { Margin }\end{array}$ & $11 \%$ & $8 \%$ & $8 \%$ & $8 \%$ & $10 \%$ & $13 \%$ & $12 \%$ & $12 \%$ & $3 \%$ & $-9 \%$ \\
\hline $\begin{array}{c}\text { Service } \\
\text { portfolio }\end{array}$ & Parts & N/A & $\begin{array}{c}\text { Parts, } \\
\text { maintenance }\end{array}$ & N/A & $\begin{array}{c}\text { Parts, } \\
\text { maintenance, } \\
\text { mobile repair } \\
\text { service }\end{array}$ & N/A & $\begin{array}{c}\text { Parts, } \\
\text { maintenance, } \\
\text { mobile repair } \\
\text { service, } \\
\text { training }\end{array}$ & N/A & $\begin{array}{c}\text { Parts, } \\
\text { maintenance, } \\
\text { mobile repair } \\
\text { service, training, } \\
\text { technical support }\end{array}$ & N/A \\
\hline $\begin{array}{c}\text { Business } \\
\text { model }\end{array}$ & $\begin{array}{l}\text { Produ } \\
\text { ct- } \\
\text { only }\end{array}$ & N/A & $\begin{array}{l}\text { Product- } \\
\text { oriented }\end{array}$ & N/A & $\begin{array}{l}\text { Product- } \\
\text { oriented }\end{array}$ & N/A & $\begin{array}{l}\text { Customer - } \\
\text { oriented }\end{array}$ & N/A & $\begin{array}{l}\text { Customer - } \\
\text { oriented }\end{array}$ & N/A \\
\hline
\end{tabular}


Table 2: Descriptive statistics and correlation

\begin{tabular}{|c|c|c|c|c|c|c|c|c|c|c|c|c|c|}
\hline No. & Variable & Obs. & Mean & $\begin{array}{l}\text { Std. } \\
\text { Dev. }\end{array}$ & Min & Max & 1 & 2 & 3 & 4 & 5 & 6 & 7 \\
\hline 1 & EBIT Margin & 1229 & 0.06 & 0.13 & -.75 & 0.52 & 1 & & & & & & \\
\hline 2 & Tobin's Q & 1153 & 1.34 & 1.06 & 0.09 & 12.18 & $0.21 *$ & 1 & & & & & \\
\hline 3 & \begin{tabular}{|l|} 
Product-oriented \\
$\mathrm{BM}^{* *}$
\end{tabular} & 522 & 0.37 & 0.48 & 0.00 & 1.00 & 0.01 & $-0.13 *$ & 1 & & & & \\
\hline 4 & \begin{tabular}{|l|} 
Customer-oriented \\
BM
\end{tabular} & 522 & 0.55 & 0.50 & 0.00 & 1.00 & -0.01 & 0.06 & $-0.85^{*}$ & 1 & & & \\
\hline 5 & R\&D/Sales (\%) & 1229 & 4.52 & 5.75 & 0.00 & 34.53 & $-0.33^{*}$ & $0.18^{*}$ & $-0.23 *$ & $0.22 *$ & 1 & & \\
\hline 6 & Number of services & 522 & 3.26 & 2.14 & 0.00 & 12.00 & -0.01 & -0.01 & $-0.34^{*}$ & $0.57 *$ & $0.18^{*}$ & 1 & \\
\hline 7 & Geo diversif. ratio $(\%)$ & 1179 & 48.07 & 27.58 & 0 & 100 & 0.05 & $-0.11 *$ & 0.07 & 0.0001 & $-0.08 *$ & -0.05 & 1 \\
\hline 8 & \begin{tabular}{|l|} 
Product diversif. \\
index
\end{tabular} & 1192 & 5.19 & 21.06 & 0.15 & 100 & $0.07 *$ & 0.03 & $-0.10^{*}$ & $0.12 *$ & $0.18 *$ & 0.03 & 0.02 \\
\hline
\end{tabular}

* Significant at 0.05 level $* * \mathrm{BM}-$ Business model 
Table 3: Results of testing Hypotheses 1-4

\begin{tabular}{|c|c|c|c|c|}
\hline & \multicolumn{2}{|c|}{ EBIT Margin } & \multicolumn{2}{|c|}{ Tobin's Q } \\
\hline & M1a & M1b & M2a & M2b \\
\hline Product-oriented $\mathrm{BM}_{1-1}$ & $0.080(0.020)$ & $0.054(0.130)$ & & \\
\hline Customer-oriented BM $\mathrm{BM}_{1-1}$ & $0.105(0.007)$ & $0.112(0.004)$ & & \\
\hline R\&D/Sales ${ }_{1-1}$ & $0.011(0.004)$ & $0.012(0.001)$ & & \\
\hline Product-oriented BM*R\&D/Sales ${ }_{1-1}$ & $-0.015(0.000)$ & $-0.00005(0.995)$ & & \\
\hline Product-oriented $\mathrm{BM} * \mathrm{R} \& \mathrm{D} /$ Sales $_{1-1}^{2}$ & & $-0.0007(0.005)$ & & \\
\hline Customer-oriented BM*R\&D/Sales ${ }_{1-1}$ & $-0.015(0.000)$ & $-0.016(0.000)$ & & \\
\hline Number of services $_{1-1}$ & $-0.012(0.003)$ & $-0.011(0.006)$ & & \\
\hline Geographical diversification ratio $_{1-1}$ & $0.0002(0.499)$ & $0.0001(0.667)$ & & \\
\hline Product market diversification $\mathrm{HI}^{*}{ }_{1-1}$ & $0.001(0.000)$ & $0.001(0.000)$ & & \\
\hline Time dummies & Omitted due $\mathrm{t}$ & ace constraints & & \\
\hline Product-oriented $\mathrm{BM}_{1-3}$ & & & $-0.367(0.099)$ & $-0.543(0.022)$ \\
\hline Customer-oriented $\mathrm{BM}_{1-3}$ & & & $-0.494(0.031)$ & $-0.471(0.039)$ \\
\hline R\&D/sales $1-3$ & & & $-0.015(0.002)$ & $-0.015(0.002)$ \\
\hline Product-oriented $\mathrm{BM} * \mathrm{R} \& \mathrm{D} /$ Sales $_{1-3}$ & & & $0.006(0.782)$ & $0.111(0.042)$ \\
\hline Product-oriented $\mathrm{BM} * \mathrm{R} \& \mathrm{D} /$ Sales $_{1-3}{ }^{2}$ & & & & $-0.006(0.037)$ \\
\hline Customer-oriented BM*R\&D/Sales ${ }_{1-3}$ & & & $0.026(0.000)$ & $0.027(0.000)$ \\
\hline Number of services $_{1-3}$ & & & $0.123(0.674)$ & $0.012(0.683)$ \\
\hline Geographical diversification ratio $_{1-3}$ & & & $-0.002(0.435)$ & $-0.001(0.598)$ \\
\hline Product market diversification $\mathrm{HI}^{*}{ }_{1-3}$ & & & $0.005(0.113)$ & $0.005(0.134)$ \\
\hline Time dummy & & & Omitted due to & pace constraints \\
\hline Number of observations & 475 & 475 & 351 & 351 \\
\hline R-squared & 0.219 & 0.235 & 0.231 & 0.245 \\
\hline F-statistics (p-value) & 0.000 & 0.000 & 0.000 & 0.000 \\
\hline
\end{tabular}

HI- Herfindahl Index

Note: p-values of coefficients are presented in the brackets 


\section{Appendix A}

\section{US SIC codes included in the sampling strategy}

\begin{tabular}{|c|c|}
\hline 10 & Metal mining \\
\hline 12 & Coal mining \\
\hline 13 & Oil and gas extraction \\
\hline 14 & Mining and quarrying of non-metallic minerals, except fuels \\
\hline 15 & Building construction-general contractors and operative builders \\
\hline 16 & Heavy construction other than building construction contractors \\
\hline 17 & Construction-special trade contractors \\
\hline 20 & Food and kindred products \\
\hline 21 & Tobacco products manufacturing \\
\hline 22 & Textile mill products manufacturing \\
\hline 23 & Apparel and other finished products made from fabrics and similar materials manufacturing \\
\hline 24 & Lumber and wood products, except furniture manufacturing \\
\hline 25 & Furniture and fixtures manufacturing \\
\hline 26 & Paper and allied products manufacturing \\
\hline 27 & Printing, publishing and allied industries \\
\hline 28 & Chemicals and allied products manufacturing \\
\hline 29 & Petroleum refining and related industries \\
\hline 30 & Rubber and miscellaneous plastics products manufacturing \\
\hline 31 & Leather and leather products manufacturing \\
\hline 32 & Stone, clay, glass and concrete products manufacturing \\
\hline 33 & Primary metal industries manufacturing \\
\hline 34 & Fabricated metal products, except machinery and transportation equipment \\
\hline 35 & Industrial and commercial machinery and computer equipment \\
\hline 36 & Electronic and other electrical equipment and components, except computer equipment \\
\hline 37 & Transportation equipment manufacturing \\
\hline 38 & $\begin{array}{l}\text { Measuring, analyzing and controlling instruments; photographic, medical and optical goods; watches } \\
\text { and clocks manufacturing }\end{array}$ \\
\hline 39 & Miscellaneous manufacturing industries \\
\hline $\begin{array}{r}874 / \\
7372 \\
\end{array}$ & Service management companies (874) with the Services-Prepackaged Software (7372) \\
\hline 386 & Photographic Equipment \& Supplies \\
\hline
\end{tabular}

\section{Sample sources and the selection criteria}

The OSIRIS database, provided by the Bureau van Dijk, represents one of the key sources on financials, ownership, subsidiaries, ratings, earnings estimates, stock data, and additional industry codes (Dow Jones Global Indexes); it has been helpful in selecting companies based on their primary SIC code. We focused on companies with primary SIC codes pertaining to industrial manufacturing, since this sector has served as the crucible for servitization strategy (Bowen et al. 1989; Gebauer et al. 2005; Neely 2008). In addition, we examined the SIC codes of 24 companies that had been cited several times in the extant literature to ensure that no relevant sector was omitted. This has led to the addition of Class 874 (service management companies), companies that have 7372 (Services-Prepackaged Software) as their secondary SIC following the example of IBM, and Class 386 (Photographic Equipment \& Supplies) following the example of Xerox (a firm renowned for pioneering a shift from selling copiers to offering document management services) (Wise and Baumgartner 1999). We chose to limit our query to listed companies because we were reliant on publicly available information detailing service approaches and on financial information accessed from secondary sources. We determined that the minimum number of employees should be one hundred, given that servitization is more likely to occur in larger firms (Neely 2008). We focused on companies operating in developed economies, since they have greater opportunities to develop and sell 
services compared to those operating in developing countries (Gebauer and Fischer 2009; Neely 2008).

After applying these criteria, we obtained a sample of 1,995 manufacturing firms and acquired their financial data from the Datastream database. After eliminating firms that missed relevant data such as product/market segment, we extracted a sample of 390 firms. We then used business descriptions to determine which companies had servitized by searching for service-related keywords defined by Neely (2008): consulting services; design and development services; financial services; installation and implementation services; leasing services; maintenance and support services; outsourcing and operating services; procurement services; property and real estate; retail and distribution services; systems and solutions; and transportation and trucking services. Of these 390 companies, 133 mentioned providing some type of 'service' in their 2008 business description. These 133 companies, therefore, provided us with the final sample used for further investigation.

\section{Data collection}

Having obtained financial data for the 1999-2009 period from Datastream, we proceeded to collect data related to servitization from publicly available sources. We selected annual reports and SIC filings since these publicly available sources are the most consistent and structured over an extended period of time (Dess and Robinson 1984; Michalisin 2001). The majority of the annual reports were found on company websites or on the website of the US Securities and Exchange Commission (Form 10-K or 20-F). When reports were unavailable for one year or more, we contacted the firms concerned requesting replacement copies. Fifty requests were sent to companies, resulting in an additional thirty annual reports. In a number of cases, though, annual reports were simply not in existence (e.g. firms were not yet listed and were, therefore, not required to file a report).

Using an established technique of expert panelists (MacCormack et al. 2001; Zott and Amit 2007), we trained a research assistant to rate, review and analyze the annual reports in relation to the aforementioned data. The advantage of using an expert panelist (expert rater) over an automated content analysis was that we secured a better understanding of the context in which the key words appeared. Furthermore, we were able to obtain a good grasp of the extent and importance of the context in which a service word appeared. This was crucial since the word 'service' appeared in many different contexts. To identify service-related sections of the annual reports, we searched each report using keywords previously used in similar studies (Neely 2008). The following keywords were identified as being most useful in discovering service-related sections of the reports: service $(s)$ - aftermarket - spare parts - customer solutions - repair - maintenance - customer relationship - training. These words were sufficient to lead us to sections of the annual report where the full service portfolio was presented. In cases where the keywords did not uncover relevant data sections, we went through each report thoroughly to make sure that services were not provided.

To code this data, we developed a structured Excel template containing the ISIN company number, company name, year of annual report, and notes on service offering. A column labeled 'notes on service offering' contained all quotations relating to the service offering retrieved from the annual report. The example below provides the 'notes on service offering' captured from the 2000 Annual Report of the Black \& Decker Corporation. It is the only quotation that refers to the types of service Black \& Decker offers. The following quotation has been used to interpret Black \& Decker's service portfolio as consisting of replacement parts and repair.

Quotation from the Black \& Decker Annual Report. 2000): 
"Replacement parts and product repair services are available through a network of company operated service centres, which are identified and listed in product information material generally included in product packaging."

\section{Data cleaning}

We encountered a number of evident outliers in our data. Following the 'three-sigma rule', we decided to exclude data points that were more than three standard deviations away from the mean for Tobin's Q (Wheeler 2001). In the case of the EBIT Margin, we opted for two standard deviations, as this meant excluding the outliers higher than $80 \%$ or lower than $-80 \%$. Applying the 'three-sigma rule' may be considered superior in theory but, in practice, it is inadequate since profit margins do not normally exceed $+/-120$ per cent. These criteria resulted in the elimination of 10 observations of EBIT Margin that were $-80 \%$ or less (there were no EBIT Margins above the $80 \%$ threshold) and two Tobin's Q ratios that were higher than 6 (there were no Tobin's Q ratios lower than $-3 \%$, which was the lower bound).

\section{Product-related services found in annual reports}

Note: obvious synonyms were eliminated.

After-market parts and supplies, parts, repair, maintenance, upgrades, facility operations services, replacement, implementation, engineering, upgrade, software licenses, monitoring, financial services, installation, renovation construction planning, component procurement, customer support, energy solutions, turn-key power solutions, development, design, production commissioning, integration, asset management, refurbishment, overhaul, product engineering to prototype construction, after-sales service, detection, attachments, on-site support, predictive maintenance programs, modernization services, preventive repairs, regulatory compliance qualification, calibration, certification and repair services, remote service support, drilling, rental, logistics, work-force accommodation, logistics services, modular building construction services; inspection, workover services, rental equipment, cutting, rig returns, offshore contracting, integration, cleaning.

\section{Customer-related services found in annual reports}

Note: obvious synonyms were eliminated

Training, consulting, application support, ongoing training, service and applications support, consulting services, toll-free telephone support, telephone support, finance, advanced technology, from single-service to full-service contracts, E-business solutions, comprehensive service offerings including Internet and eBusiness solutions - from on-line spare parts ordering, to complete plant documentation, to on-line remote diagnostics of a customer's equipment, internet-based platforms, procurement, construction, commissioning, operations and maintenance services, rental (short- or long-term rentals, customized rental programs), national account programs, equipment delivery and pick up, 24/7 customer care, advisory services, software maintenance, asset management, installation, advertising and sales promotions, order-entry and tracking systems and an annual restocking program, after-market activities, parts, technical services, comprehensive technical customer training, day-to-day operation, audits, certification programs and professional development courses, financial services, training manuals, decision-support systems and performance-based contracts, commissioning, customer support, product launch coordination, direct advertising, specialized sales material development, help desks, order entry, marketing strategy and field service support, accounting, legal, engineering and electrical contracting services, specialized training programs, materials logistics and quality management, storage. 